\title{
12
}

\section{THE EUROPEANIZATION OF BELGIAN PARTIES}

\section{Both near and far?}

\section{Louise Hoon and Gilles Pittoors}

\subsection{Introduction}

The process of European integration has forced political parties to reinvent and adapt themselves in different ways. Presenting them with a new level of competition and governance, national party politicians take part in European decision-making and compete in European Parliament elections. Over the past two decades, the politicization of European integration and the rise of Euroscepticism have forced political parties to take a clear stance on Europe and adapt their organizations to the new multilevel context. This adjustment of party programs and organizations to the European Union (EU) can be defined as the 'Europeanization' of political parties. This process presents us with many interesting questions. Why, where and how do parties Europeanize, which incentives are at play and does the tendency to Europeanize vary across parties?

These questions are even more interesting in the exceptional case of Belgium, where Europe is both near and far. The country may rightfully be described as the historical, geographical and institutional heart of the EU. Belgium was the main battlefield of two world wars that incited political elites to seek integration. High-profile Belgian politicians have taken up leading roles in the EU's history and institutions. And obviously, its political capital of Brussels physically hosts the European institutions and its community of public officials, civil society representatives and other expats from all over the EU.

At the same time, the EU remains remarkably depoliticized. The deep polarization between pro- and anti-European parties that can be observed in most other member states, long remained surprisingly absent in Belgium (Brack \& Hoon, 2017). Whereas both the radical left and right are voicing more critical positions toward the EU today, Euroscepticism is still not the warhorse it is for ideologically similar parties in other member states. 
Against that background, this chapter studies the organizational and programmatic Europeanization of Belgian political parties. Through qualitative analysis of Belgian party statutes and manifestos, we show how challenger and mainstream parties show different patterns to Europeanize in different ways, the former showing more programmatic and the latter more organizational Europeanization. At the same time, we find patterns of Europeanization specific to party family and ideology and to the particular context of Belgium.

The chapter first outlines the literature on party Europeanization, highlighting historical differences in challenger and mainstream parties' interactions with Europe. The second part presents data and methods, followed by the analysis that addresses organizational Europeanization before moving on to the party programs. The chapter ends with a discussion of our findings, identifying a path for further research as well as the shortcomings of the study.

\subsection{The Europeanization of political parties}

Europeanization is understood as domestic adaptation to European integration (Caporaso, 2008; Ladrech, 1994; Olsen, 2002; Radaelli \& Pasquier, 2008; Risse et al., 2001). Featherstone and Radaelli (2003) convincingly argued that Europeanization refers to the incorporation of European "ways of doings things" in "the logic of domestic discourse, identities, political structures, and public policies" (p. 30). Focusing on the Europeanization of political parties, Ladrech (2002) laid out a robust research agenda, outlining five arenas in which national parties could feel an impact of European integration-programs, organization, competition, government and transnational relations.

On the one hand, most scholarly attention went to the extent to which parties incorporated the EU in their party programs and competitive positions (programmatic Europeanization). It is well established that so-called challenger parties initiated and drive EU politicization. Emphasizing a topic that mainstream parties long ignored proved a highly effective strategy to restructure domestic party competition (Braun et al., 2016; De Vries \& Hobolt, 2020; Grande \& Hutter, 2016; Grande \& Kriesi, 2016; Green-Pedersen, 2019; Hobolt \& de Vries, 2016; Mair, 2000, 2007). Especially those opposing the EU by means of Euroscepticism reaped the electoral benefits of this challenger strategy (Meijers \& Rauh, 2016). Over the past two decades, Eurosceptic parties became the first or second competitors in all but a few member states and entered government in Austria, Italy, Greece and a number of Eastern European countries (Brack \& Startin, 2015).

On the other hand, although there is a long and extensive literature on national parties' engagement in European party federations (Bomberg, 2002; Cole, 2001; Daniels, 1998; Hanley, 2002, 2008; Pridham, 2001; Pridham \& Pridham, 1981; Van Hecke, 2009, 2010), comparatively little attention was given to the extent to which political parties organizationally adapt to the EU (organizational Europeanization). Most of the earlier studies on organizational 
Europeanization presented rather sobering conclusions that parties adapt very little to the EU, and that organizational change can hardly be attributed to the EU as an external cause (Ladrech, 2012; Poguntke et al., 2007; Raunio, 2000, 2002). Recent studies slightly alter that image, highlighting variation in the way parties organize in the EU context (Mühlböck, 2017; Pittoors, 2020). This variation may be explained by contextual factors, such as the degree to which national institutions and political practices 'fit' the EU's political structures or the extent to which the EU is politicized within a country, although the jury is still out on what exactly explains this variation (Featherstone \& Radaelli, 2003; Green Cowles et al., 2001; Mastenbroek \& Kaeding, 2006; Schmidt, 2006).

Therefore, we take the opportunity of closely studying the exceptional case of Belgium to gain deeper understanding of within-country variation in party Europeanization, whereby we expect variation to depend on a party's status as challenger or mainstream party. For one, mainstream and challenger parties are presented with different incentives for organizational Europeanization. Parties from the three traditional party families (liberal, socialist and Christian democrat) have been the main initiators and entrepreneurs of European integration. They thus have long-standing traditions of cooperation in European party federations and European Parliament groups. In the tradition of Duverger (1954) and Panebianco (1988), we assume this historical interlacing with European politics is bound to show in mainstream parties' contemporary organization.

Not only do these politicians inhabit the European institutions and drive the EU's decision-making process, but also given how "decisions made at the EU level increasingly shape national policies, and hence directly mold the environment within which national parties operate" (Poguntke et al., 2007, p. 2), domestic politics also requires attention for the European level. To be efficient at navigating this multilevel institutional environment and pursuing their party goals - be it votes, offices or policy (Harmel \& Janda, 1994) - these parties are required to acquire dedicated personnel and to engage in transnational bargaining, cooperation and consensus-seeking.

By contrast, both by choice and by the institutional design and political practice of the EU, challengers have historically been sidelined from European integration and decision-making processes. This is even true for the European Parliament, where about a third of the seats are now taken by Eurosceptic or challenger parties. For instance, despite some indications that radical rights are increasingly organizing transnationally (McDonnell \& Werner, 2019; Startin \& Brack, 2018), this is still a far cry away from the decades experience with transnational cooperation known to the Christian democrats and the EPP, nor have they been at the center of politico-institutional power in Europe, with all the organizational consequences this entails. It is therefore not unreasonable to expect that challenger parties will exhibit much less organizational Europeanization than mainstream parties. 
H1: We expect organizational Europeanization to be more prominent with mainstream parties, and less with challengers

When it comes to programmatic Europeanization, we follow the literature in our expectation that challenger parties will be more likely to politicize the EU (Hobolt \& de Vries, 2016). However, our qualitative approach allows us to add a meaningful and often overlooked dimension to programmatic Europeanization. EU politicization is generally understood and measured as the contestation of the EU as such. The contestation of its overall existence, foundations and workings has been at focus of EU politicization. In contrast to this politicization of constitutional issues, there is less attention for the politicization of substantial issues, i.e. the content, direction and political nature of European policy (De Wilde \& Zürn, 2012).

For better understanding, we may align this distinction between constitutional and substantial issues to Dahl's (1969) concepts of polity opposition and policy opposition. Whereas polity opposition rejects the political system and its legitimacy as a whole, policy opposition is aimed at the content or direction of European policy, the division of funds or at EU-level politicians.

The distinction between constitutional and substantial EU politicization allows us to nuance the established image of challenger-led EU politicization and of mainstream parties anxiously keeping the EU off the political agenda (Kriesi, 2016; Mair, 2007). Considering their active and prominent role in the European integration and decision-making process, mainstream parties seem more likely to engage in the politicization of substantial European issues. For example, their proposals in a particular policy area or the achievements of their EP party group. For challengers, on the other hand, it seems more convenient and effective to treat the EU as a monolithic entity that one either entirely rejects or entirely supports and is thus a complicit part of.

H2: When it comes to programmatic Europeanization, we expect challenger parties to stress constitutional issues, and mainstream parties to stress substantial issues

\subsection{Measuring party Europeanization}

Our understanding of programmatic Europeanization predominantly relies on large-scale, European wide quantitative survey research. It focuses on voters' and parties' positions on binary opinion and expert survey scales, most notably the ten- or seven-point pro- and anti-EU integration scale introduced by Leonard Ray (1999). Inevitably, this approach has favored a focus on polarization on constitutional issues or the pro-/anti-European integration scale (Hooghe \& Marks, 2009, 2018; Jackson \& Jolly, 2021; Kriesi, 2016).

In the party organization literature, we find a much wider arrange of qualitative and quantitative methods and approaches to Europeanization. This strand of 
the literature, however, has so far paid less attention to how parties' mainstream or challenger status may present parties with different incentives for Europeanization. Combining methods and insights from both strands of the literature, we aim to present a more nuanced and understanding of interparty variation in Europeanization.

The corpus consists of party statutes and party manifestos from the relevant parties participating in the election. To measure organizational Europeanization, we check the latest party statutes for mentions of the EU, European integration or EU mandatories. Building on previous work on party statutes (Deschouwer \& Van Assche, 2003), the statutes are analyzed by looking at four indicators: (1) references to Europe in the preambles; (2) reference to the representation of EU mandatories in relevant party bodies (e.g. party board or council); (3) reference to specific bodies or functions dealing with European affairs (e.g. a European secretary or interparliamentary format) and (4) references to the Europarty the national party is a member of.

This data are gathered in an 'old school' way, meaning not through coding but through actual reading and interpreting. The reason for using this method is that the aim of this study is not to study the number of 'mentions' of Europe in the statutes but rather to qualify the concrete organization of a political party. It should be noted, however, that statutes do not always fully reflect the practical reality of parties' organization. Still, these documents suggest the way a party thinks about itself and one can, hence, assume that if a party "makes the effort to mention Europe in its statutes, it is any case, an indication that the European level has consequences for the way a party works" (Deschouwer \& Van Assche, 2003, pp. 122-123, own translation).

To identify programmatic Europeanization, election manifestos are the most adequate source of information. We use Nvivo Qualitative Data Analysis Software to scout references to the EU (using the terms 'EU', 'Europese' and 'Eur`') and code them according to their substantial or constitutive nature. For each reference, we also indicate whether it supports (positively refers to) or opposes (negatively refers to) the EU. N-vivo allows us to quantitatively compare the different types of references to EU and to closely compare them for each party. The election manifestos under study were all presented in the run-up to the 2019 regional, federal and European Parliament elections. Some parties presented separate manifestos for the different levels. But because 'Europeanization' refers to domestic adaptation to European integration, we choose to include only the 'main' or federal election manifesto for each party.

Following Hobolt and De Vries (2016), we define challengers as parties that, in their style, organization and program, explicitly differentiate themselves from the established political elites and/or have never taken part in government before and/or 'own' political issues that do not belong to the dominant dimension of political competition. All three criteria apply to the Flemish radicalleft PTB-PVDA and to the radical-right VB. The Greens and the Flemish nationalist N-VA have taken part in government and currently govern either 
TABLE 12.1 List of parties under study

\begin{tabular}{|c|c|c|c|}
\hline Party & Full name & Status & Ideology \\
\hline $\mathrm{CD} \& \mathrm{~V}$ & $\begin{array}{l}\text { Christen-Democratisch en } \\
\text { Vlaams }\end{array}$ & Mainstream & Christian democrat \\
\hline $\mathrm{CDh}$ & Centre Démocrate Humaniste & Mainstream & Christian democrat \\
\hline OVLD & $\begin{array}{l}\text { Open Vlaamse Liberalen en } \\
\text { Democraten }\end{array}$ & Mainstream & Liberal \\
\hline MR & Mouvement Réformateur & Mainstream & Liberal \\
\hline sp.a & Socialistische Partij Anders & Mainstream & Social democrat \\
\hline PS & Parti Socialiste & Mainstream & Social democrat \\
\hline Groen & Groen & Challenger & Green \\
\hline Ecolo & $\begin{array}{l}\text { Ecologistes Confédérés pour } \\
\text { l'Organisation de Luttes } \\
\text { Originales }\end{array}$ & Challenger & Green \\
\hline N-VA & Nieuw-Vlaamse Alliantie & Challenger & Nationalist \\
\hline Défi & $\begin{array}{l}\text { Démocrate Fédéraliste } \\
\text { Indépendant }\end{array}$ & Challenger & Regionalist \\
\hline PTB-PVDA & $\begin{array}{l}\text { Parti du Travail de Belgique- } \\
\text { Partij van de Arbeid van België }\end{array}$ & Challenger & Radical left \\
\hline VB & Vlaams Belang & Challenger & Radical right \\
\hline
\end{tabular}

at federal or regional level. N-VA, in addition, has been the largest party of Flanders since the 2014 elections. Nevertheless, looking from the federal level, these parties also clearly hold a challenger status: N-VA because of its expressed Flemish nationalism and overt opposition to the Belgian federal state, and the Greens for their adherence to issues alternative to the dominant left-right dimension. DéFi, lastly, is a small party that - in reaction to Flemish nationalismdefends the interests of francophone citizens in and around Brussels, and thus, despite being in the Brussels regional government, also challenges the Belgian political status quo. Table 12.1 lists all parties under study.

\subsection{Analysis of party Europeanization}

\subsubsection{Organizational Europeanization}

Assessing the results of the qualitative study of party statutes (Table 12.2), we see clear differences between mainstream and challenger parties, with the latter on average paying less attention to Europe in their statutes. At the same time, significant differences exist within each of these groups; e.g. between the Greens and the radical right within the challenger group, or between the mainstream social democrats and liberals. This could indicate that organizational differences between parties has more to do with their (historical) development and party family (Duverger, 1954; Panebianco, 1988), rather than their status as mainstream or challenger party.

Generally, most Belgian parties make some kind of reference to Europe in their preambles. Even the radical right VB refers to the "European peoples, 
TABLE 12.2 Organizational Europeanization of Belgian parties

CDEV N-VA OVLD sp.a Groen $\quad V B \quad$ PTB-PVDA $\quad$ CDH $\quad$ MR $\quad$ PS $\quad$ Ecolo Défi

A. Representation of EU mandataries in party governing bodies

Ex officio members of the party board

$\times \quad \times$

$x+x$

Ex officio advisory members of the party board; can

be elected to gain voting rights

Ex officio advisory members of the party board

Not ex officio members of party board; can be elected

Ex officio members of the party council, not of the

party board

Not statutorily represented/No mention

Explicit mention of EU and Europarty

General reference to European cooperation

General reference to Europe as a cultural and/or geographic area

Reference only to Europarty membership

No reference to Europe

Specific body exists to manage EU affairs and coordination + explicit involvement of party

board/president

Specific body exists to manage EU affairs and

coordination

Coordination is responsibility of nonspecific body

(e.g. EU mandatories themselves)

No mention

Explicit mention of Europarty and ways of interacting

General mention of Europarty

No mention

B. Mention of Europe/EU in party statute preambles

$x$

$\times$

C. Mention of bodies specifically dedicated to EU affairs

D. Mention of Europarty 
civilization and cultural community" (own translation) to which it belongs. Surprisingly, the liberal parties-Belgium's most outspoken pro-EU familymention Europe least in their preambles, with OVLD only mentioning their ALDE membership and MR not mentioning Europe at all. There are also clear differences in the references to Europarty membership, although not particularly along the mainstream/challenger axis: while the Greens make references to the EGP, none of the other challenger parties mention Europarties but neither does the mainstream $\mathrm{MR}$ or $\mathrm{CDH}$.

The statutes for the most part also provide ample details about the representation of EU mandataries in their party bodies. In most parties, MEPs (or the EP delegation leader) are ex officio members of an executive body-usually the party board or bureau. Parties vary in terms of voting rights for these mandataries: in some parties, they have them automatically (e.g. the Green and Christian democrat parties), while in others, only advisory membership is guaranteed and they need to get elected to attain voting rights (e.g. the Flemish liberals). Here, the radical left and right somewhat stand out. Whereas VB MEPs are only ex officio welcome in the party council (and not the party board), PTB-PVDA even remains silent on the representation of EU mandatories in its bodies.

The differences between challenger and mainstream parties are most obvious, however, regarding the internal management of European affairs by specific bodies or people. With the exception of the N-VA, none the of the challenger parties make any reference to them at all (although these do exist in reality, particularly in the Green parties). By contrast, all mainstream parties mention such people or bodies in various forms. For example, the MR statutes describe an "intergroupe parlementaire" to organize relations between the party's national and European parliamentarians, while the PS has a whole section dedicated solely to how and by whom relations with the PES are managed. Challenger parties thus elaborate much less on their organizational ties with the European level than mainstream parties.

That the difference between challenger and mainstream parties is most obvious in their organizational linking of the national and European levels, but much less so in their framing of their own activities in European terms, highlights how the 'proximity' of Belgium to the EU, i.e. being its historical and political heart, seems to seep through to party organizations in the sense that most Belgian parties cannot seriously claim to act in a purely Belgian context. Indeed, it cannot be denied that also the liberal parties, if not in their statutes, regularly refer to Europe in their public communication. This particularity of Belgium of course requires more comparative study but a quick look at their Dutch counterparts already shows a striking difference: with the exception of the Europhile D66, not a single Dutch party makes any reference to Europe at all in their statutes' preambles.

Moreover, these findings also support our argument for the importance of the historical development of parties and their organizations. Indeed, that the main difference between the two should be located in the extent to which they 
created specific bodies for connecting the national and European governance levels falls entirely in line with the idea that mainstream parties historically had both more resources and incentives to do so, given their long-term involvement in European cooperation and EU decision-making.

That being said, however, one must also recognize that there is significant variation within each group, suggesting that (further) differences might be based on ideological family. For example, the Greens are just as similar/different to the Christian democrats as they are to the radical left and right. Moreover, the liberal parties stand out, providing little detail on their parties' organization regarding the EU-in fact doing less so than the Greens. The difference with particularly the social democrat parties could not be greater. Indeed, no other party family has statutes that address the EU in such detail; from their EU mandatories' ex officio representation in party bodies, to extensively referring to their Europarty membership and multilevel coordination bodies (e.g. the PS' "Conseil des Représentants des Socialistes européens") and the explicit involvement of the party leadership.

These findings qualify the differences between challenger and mainstream parties, hinting at the notion that the organization of political parties and their Europeanization has to do with their (historical) development and party family (Panebianco, 1988), rather than their status as mainstream or challenger party. Of course, given how statutes give a distorted view of reality, one should remain cautious about such conclusions.

\subsubsection{Programmatic Europeanization}

As we have coded all text referring to the EU as supportive or opposing and as focused either on substantial or constitutional issues, Nvivo allows us to calculate the total amount of text that each party attributes to the EU, for each one of those categories. For each manifesto, these numbers are presented as a percentage of the total length of the manifesto in Table 12.3. In Table 12.4,

TABLE 12.3 Programmatic Europeanization of Belgian parties

\begin{tabular}{lccccccccccccc}
\hline \multicolumn{1}{c}{ PTB- } & PVDA & Groen & Ecolo & $N$-VA & Defi & $V B$ & sp.a & PS & OVLD & $M R$ & CDEV & $C D H$ \\
\hline Constitutional & & & & & & & & & & & \\
Positive & 0.14 & 0.06 & 0.19 & 1.33 & 0.20 & 0 & 0.29 & 0.49 & 0.35 & 0.11 & 0.06 & $(7)$ & 0.15 \\
& $(5)$ & $(3)$ & $(3)$ & $(21)$ & $(12)$ & & $(8)$ & $(35)$ & $(7)$ & $(5)$ & & $(10)$ \\
Negative & 0.31 & 0.01 & 0.16 & 1.33 & 0.01 & 1.27 & 0.16 & 0.16 & 0.20 & 0 & 0 & 0.06 \\
& $(11)$ & $(1)$ & $(2)$ & $(16)$ & $(1)$ & $(5)$ & $(4)$ & $(11)$ & $(2)$ & & & $(2)$ \\
Substantial & & & & & & & & & & & & \\
Positive & 0.71 & 1.18 & 1.90 & 1.15 & 1.14 & 0.20 & 2.44 & 2.58 & 1.77 & 1.34 & 1.45 & 1.26 \\
& $(36)$ & $(40)$ & $(42)$ & $(47)$ & $(101)$ & $(4)$ & $(99)$ & $(380)$ & $(26)$ & $(78)$ & $(140)$ & $(85)$ \\
Negative & 0.31 & 0.01 & 0.16 & 1.03 & 0.01 & 1.27 & 0.16 & 0.16 & 0.20 & 0 & 0.05 & $(4)$ & 0.25 \\
& $(13)$ & $(1)$ & $(3)$ & $(23)$ & $(1)$ & $(9)$ & $(4)$ & $(14)$ & $(3)$ & & & $(12)$ \\
\hline
\end{tabular}


TABLE 12.4 Average programmatic Europeanization per party family

\begin{tabular}{lccccc}
\hline & \multicolumn{2}{c}{ Constitutional } & \multicolumn{2}{c}{ Substantial } \\
\hline & Negative & Positive & Negative & Positive & Total \\
\hline Mainstream & 0.10 & 0.24 & 0.14 & 1.81 & 2.29 \\
Christian democrat & 0.03 & 0.11 & 0.15 & 1.35 & 1.64 \\
Social democrat & 0.16 & 0.18 & 0.16 & 2.51 & 3.01 \\
Liberal & 0.10 & 0.39 & 0.10 & 1.54 & 2.13 \\
Challenger & 0.52 & 0.32 & 0.52 & 1.05 & 2.41 \\
Radical left & 0.31 & 0.14 & 0.31 & 0.71 & 1.47 \\
Radical right & $\mathbf{1 . 2 7}$ & 0 & 1.27 & 0.20 & 2.74 \\
Green & 0.09 & 0.13 & 0.09 & 1.54 & 1.85 \\
Regionalist & 0.67 & 0.77 & 0.64 & 0.67 & 2.75 \\
\hline
\end{tabular}

the average percentage for each party family is calculated, which allows us to compare the patterns of programmatic Europeanization with mainstream and challenger parties.

First, the amount and detail of the references that we find in the manifestos contradicts the idea that Europe would be a nonissue in Belgium. In total, $2.29 \%$ of mainstream parties' manifestos refer to the EU or to European policy. Contrary to what we might expect from the literature on EU politicization by challenger parties, that number is a little lower for challenger parties: $2.41 \%$. This programmatic Europeanization is overwhelmingly substantial and positive. Most references are supportive of specific EU policies and action in particular domains. Repeatedly, parties argue for compliance with one or another EU regulation, directive or recommendation, or justify their domestic policy proposals by mentioning how the EU is already prioritizing them.

The debate over European integration and the EU as a whole (constitutional Europeanization) appears less prominent in Belgian manifestos. Overall, it is only slightly more negative than positive. It is also remarkable that none of the Belgian parties argues for an 'exit' from the EU, nor for a referendum on EU membership. The low level of polarization on pro-/anti-EU issues might explain why Belgium is often (wrongly) perceived as a country where Europe 'does not matter'.

Second, and in line with $\mathrm{H} 2$, challenger parties stress constitutional issues more than mainstream parties. On average, about $0.85 \%$ of the text in challenger party programs is dedicated to opposition to the EU as a whole. Radical right parties clearly voice the more negative tone of these references, whereas Green parties are not outspokenly more positive than the mainstream.

As we expected, mainstream parties spend about two and a half times less text on constitutional European issues (0.35\%) than challenger parties do. Instead, they write about twice as much about substantial European issues (about 3\% to $1.6 \%$ ), and overwhelmingly in a supportive tone. However, the pattern of programmatic Europeanization on constitutional issues within the challenger group 
is less outspoken than expected. In fact, once we exclude the radical right, challenger parties are not that different from the mainstream. The regionalist N-VA shows a striking number of positive references to the EU as a whole.

Considering the transnational nature of ecological issues and the established idea that GAL or Green-Alternative-Liberal parties are generally outspokenly pro-European, we would expect Green parties to express more support for the EU as a whole. But the mainstream, social democratic parties spend more text on supporting the EU. Taking part in government at several levels, Belgian Green parties may not fit the 'challenger' category well. But the finding also indicates that, beyond mainstream or challenger status, party family and institutional history matter for Europeanization.

A close reading of all coded references to Europe allows us to identify some additional patterns. First, what stands out from a close reading of all negative, constitutional references is that especially the challenger parties tend to add suggestions for (radically) alternative models of European integration to their opposition to the EU. The N-VA program especially contains plenty of equivocal references to the EU, combining support for the general idea of EU integration with critical remarks about its practice and proposals for improvement regarding its efficiency and democratic legitimacy. But this type of reference can also be found with the most Eurosceptic parties in our study, the extreme-left PTB and the radical right VB. Both parties praise the Belgian and-for VB-Flemish economic, cultural and political interconnectedness in the European context.

Second, the regionalist parties in our study (VB, N-VA and Défi) tend to use the European context to discard the federal level. VB and N-VA emphasize Flemish and European culture and identity in these references. For Défi, the focus is on institutions and policy. The party repeatedly describes regional policies and institutions and their direct interaction with the European context, somewhat 'skipping stresses the embedding of regional policies in their European context, as well as the role of Brussels as a European (rather than Belgian) capital. Regionalist Euroskepticism appears to balance between opposing Europe and supporting it as a vehicle for regional independence.

\subsection{Conclusion}

This chapter addresses the Europeanization of political parties in the exceptional context of Belgium, where Europe is both near and far. Whereas the jury is still out on whether the EU is a politicized topic at the national level or not, there is no doubt that it is exceptionally low in Belgium (Braun \& Grande, 2021; Braun et al., 2020; Green-Pedersen, 2019). At the same time, however, there is no other EU member state for which Europe is so close by, given the proximity of Brussels and the EU institutions. Ever so strikingly, therefore, at the historic and political heart of the EU, political parties seem to refrain from competition over European integration. 
However, our study shows that this image of EU depoliticization in Belgium is incomplete. Our analysis of party statutes and manifestos shows that there is definitely domestic adjustment to Europe with Belgian parties. Mainstream parties exhibit more organizational Europeanization and are more likely to incorporate Europe in a substantial and positive way in their manifestos. Challenger parties, by contrast, Europeanize less organizationally, while they are slightly more inclined to reject the EU as a whole on the programmatic level. However, we also found that there is variation in Europeanization within challenger and mainstream categories, highlighting the importance of their ideological, party family and historic background (Duverger, 1954; Koskimaa, 2020; Panebianco, 1988).

As such, despite being often considered a country where Europe doesn't matter, our study highlights that Belgium shows very particular patterns of party Europeanization, further supporting the claim of its exceptional status in Europe. On the one hand, Belgian parties have adapted markedly to the EU, arguably more so than parties in other (Western European) member states. For instance, a quick look at the Dutch statutes shows that, with the exception of D66, not a single Dutch party refers to the EU in its statute preambles and very rarely mentions their Europarty. On the other hand, whereas Belgian parties do not compete so much about the EU as a whole, they do integrate substantial European issues in their party programs, voicing not only support but also substantial opposition. Associating our findings to the literature, the Belgian pattern seems quite exceptional. Existing studies of party positioning and EU politicization predominantly show a pattern of polarization on the (constitutional) pro/-anti-European integration dimension in the EU as a whole (Jackson \& Jolly, 2021), as well as for particular countries and regions (Charalambous et al., 2018; Vachudova, 2019). Comparing these patterns of Europeanization to those of other countries provides a path for further research.

Finally, a few shortcomings of this study must be addressed. First, whereas Europeanization is a complex and multidimensional process, we have only looked at its organizational and programmatic aspects here, leaving other ways in which parties can Europeanize, such as their transnational relations and behavior in government, unaddressed (Ladrech, 2002). Second, we have only analyzed official documents (party statutes and manifestos), which do not necessarily reflect the behavior of party officials, or the reality of party competition and internal organization. Third, our focus on variation between parties in Belgium prevents us from explicitly generalizing our findings for mainstream and challenger parties in the EU. Future research is thus encouraged to engage in a comparative study of programmatic and organizational Europeanization in several member states.

\section{References}

Bomberg, E. (2002). The Europeanisation of Green Parties: Exploring the EU's Impact. West European Politics 25(3): 29-50. 
Brack, N., \& Startin, N. (2015). Introduction: Euroscepticism, from the Margins to the Mainstream. International Political Science Review 36(3), 239-249.

Brack, N. \& Hoon, L. (2017). Euroscepticism in Belgium. Issue-Voting Against the Odds. In J. H. Nielsen \& M. N. Franklin (Eds.), The Eurosceptic 2014 European Parliament Elections. London: Palgrave Macmillan, pp. 171-195.

Braun, D. \& Grande, E. (2021). Politicizing Europe in Elections to the European Parliament (1994-2019): The Crucial Role of Mainstream Parties. JCMS: Journal of Common Market Studies (published online): 1-18.

Braun, D., Gross, M., \& Rittberger, B. (2020). Political Behaviour in the EU Multi-Level System. Politics and Governance 8(1): 1-5.

Braun, D., Hutter, S., \& Kerscher,A. (2016). What Type of Europe? The Salience of Polity and Policy Issues in European Parliament Elections. European Union Politics 17(4): 570-592.

Caporaso, J. A. (2008). The Three Worlds of Regional Integration Theory. In P. Graziano \& M. Vink (Eds.), Europeanization: New Research Agendas. Basingstoke: Palgrave Macmillan, pp. 23-45.

Charalambous, G., Conti, N. \& Pedrazzani,A. (2018). The Political Contestation of European Integration in Southern Europe. Friction Among and Within Parties. Party Politics 24(1): 39-51.

Cole, A. (2001). National and Partisan Contexts of Europeanization:The Case of the French Socialists. JCMS: Journal of Common Market Studies 39(1): 15-36.

Dahl, R. A. (1969). Political Opposition in Western Democracies. In J. Blondel (Ed.), Comparative Government. London: Palgrave Macmillan, pp. 229-234.

Daniels, P. (1998). From Hostility to 'Constructive Engagement': The Europeanisation of the Labour Party. West European Politics 21(1): 72-96.

DeVries, C. \& Hobolt, S. (2020). The Rise of Challenger Parties. Political Insight 11(3): 16-19.

De Wilde, P. \& Zürn, M. (2012). Can the Politicization of European Integration be Reversed? Journal of Common Market Studies 50(S1): 137-153.

Deschouwer, K. \&Van Assche, M. (2003). Europeanisering en centralisering. Een verkennend onderzoek naar de plaats van de Europese Unie in de organisatie van de Belgische politieke partijen. Res Publica 45(1): 121-142.

Duverger, M. (1954). Political Parties: Their Activity and Organization in the Modern State. London: Methuen \& Company Limited.

Featherstone, K. \& Radaelli, C. (Eds.) (2003). The Politics of Europeanization. Oxford: Oxford University Press.

Grande, E. \& Hutter, S. (2016). Beyond Authority Transfer: Explaining the Politicisation of Europe. West European Politics 39(1): 23-43.

Grande, E. \& Kriesi, H. (2016). Conclusions: The Post-Functionalists Were (Almost) Right. In S. Hutter, E. Grande, \& H. Kriesi (Eds.), Politicising Europe: Integration and Mass Politics. Cambridge: Cambridge University Press, pp. 279-300.

Green Cowles, M., Caporaso, J., \& Risse,T. (Eds.). (2001). Transforming Europe Europeanization and Domestic Change. Ithaca, NY: Cornell University Press.

Green-Pedersen, C. (2019). The Reshaping of West European Party Politics. Agenda-Setting and Party Competition in Comparative Perspective. Oxford: Oxford University Press.

Hanley, D. (2002). Christian-Democracy and the Paradoxes of Europeanization. Flexibility, Competition and Collusion. Party Politics 8(4): 463-481.

Hanley, D. (2008). Beyond the Nation State. Parties in the Era of European Integration. London: Palgrave Macmillan.

Harmel, R. \& Janda, K. (1994). An Integrated Theory of Party Goals and Party Change. Journal of Theoretical Politics 6(3): 259-287.

Hobolt, S. B. \& de Vries, C. (2016). Turning Against the Union? The Impact of the Crisis on the Eurosceptic Vote in the 2014 European Parliament Elections. Electoral Studies 44: 504-514. 
Hooghe, L. \& Marks, G. (2009). A Post-Functionalist Theory of European Integration: From Permissive Consensus to Constraining Dissensus. British Journal of Political Science 39(1): $1-23$.

Hooghe, L. \& Marks, G. (2018). Cleavage Theory Meets Europe's Crises: Lipset, Rokkan and the Transnational Cleavage. Journal of European Public Policy 25(1): 109-135.

Jackson, D. \& Jolly, S. (2021). A New Divide? Assessing the Transnational-Nationalist Dimension among Political Parties and the Public across the EU. European Union Politics 24(1): 39-51.

Koskimaa, V. (2020). The 'Genetic' Effect: Can Parties' Past Organizational Choices Condition the Development of Their Internal Distribution of Power in the Cartel Party Era? Evidence from Finland, 1983-2017. Politics (published online): 1-19.

Kriesi, H. (2016). The Politicization of European Integration. JCMS: Journal of Common Market Studies 54(1): 32-47.

Ladrech, R. (1994). Europeanization of Domestic Politics and Institutions: The Case of France. JCMS: Journal of Common Market Studies 32(1): 69-88.

Ladrech, R. (2002). Europeanization and Political Parties:Towards a Framework for Analysis. Party Politics 8(4): 389-403.

Ladrech, R. (2012). Party Change and Europeanisation: Elements of an Integrated Approach. West European Politics 35(3): 574-588.

Mair, P. (2000). The Limited Impact of Europe on National Party Systems. West European Politics 23(4): 27-51.

Mair, P. (2007). Political Opposition and the European Union. Government and Opposition 42(1): 1-17.

Mastenbroek, E. \& Kaeding, M. (2006). Europeanization Beyond the Goodness of Fit: Domestic Politics in the Forefront. Comparative European Politics 4(4): 331-354.

McDonnell, D. \& Werner, A. (2019). International Populism. In The Radical Right in the European Parliament. Oxford: Oxford University Press.

Meijers, M. J. \& Rauh, C. (2016). Has Euroscpetic Mobilisation Become More Contagious? Comparing the 2009 and 2014 EP Election Campaigns in The Netherlands and France. Politics and Governance 4(1): 83-103.

Mühlböck, M. (2017). Voting Unity of National Parties in Bicameral EU Decision-Making: Speaking with One Voice? New York, NY: Palgrave Macmillan.

Olsen, J. P. (2002). The Many Faces of Europeanization. JCMS: Journal of Common Market Studies 40(5): 921-952.

Panebianco, A. (1988). Political Parties: Organisation and Power. Cambridge: Cambridge University Press.

Pittoors, G. (2020). Living Apart Together? The Organization of Political Parties beyond the Nation-State:The Flemish Case. Politics and Governance 8(1): 50-60.

Poguntke, T., Aylott, N., Carter, E., Ladrech, R., \& Luther, K. R. (Eds.). (2007). The Europeanization of National Political Parties. Power and Organizational Adaptation. New York, NY: Routledge.

Poguntke, T., Aylott, N., Ladrech, R., \& Luther, K. R. (2007). The Europeanisation of National Party Organisations: A Conceptual Analysis. European Journal of Political Research 46(6): 747-771.

Pridham, G. (2001). Patterns of Europeanization and Transnational Party Co-Operation: Party Development in Central and Eastern Europe. In P. G. Lewis (Ed.), Party Development and Democratic Change in Post-Communist Europe: The First Decade. London: Routledge, pp. 179-198.

Pridham, G. \& Pridham, P. (1981). Transnational Party Co-Operation and European Integration: The Process Towards Direct Elections. London: Allen \& Unwin. 
Radaelli, C. \& Pasquier, R. (2008). Conceptual Issues. In P. Graziano \& M. Vink (Eds.), Europeanization: New Research Agendas. Basingstoke: Palgrave Macmillan, pp. 35-45.

Ray, L. (1999). Measuring Party Orientations towards European Integration: Results from an Expert Survey. European Journal of Political Research 36(2): 283-306.

Raunio, T. (2000). Losing Independence or Finally Gaining Recognition? Contacts Between MEPs and National Parties. Party Politics 6(2): 211-223.

Raunio, T. (2002). Why European Integration Increases Leadership Autonomy within Political Parties. Party Politics 8(4): 405-422.

Risse,T., Green Cowles, M., \& Caporaso,J.A. (2001). Europeanization and Domestic Change: Introduction. In M. Green Cowles, J. A. Caporaso, \& T. Risse (Eds.), Transforming Europe: Europeanization and Domestic Change. Ithaca, NY: Cornell University Press, pp. 1-20.

Schmidt, V. A. (2006). Democracy in Europe. The EU and National Polities. Oxford: Oxford University Press.

Startin, N. \& Brack, N. (2018). To Cooperate or Not To Cooperate? The European Radical Right and Pan-European Cooperation. In J. FitzGibbon, B. Leruth, \& N. Startin (Eds.), Euroscepticism as a Transnational and Pan-European Phenomenon: The Emergence of a New Sphere of Opposition. London: Routledge, pp. 42-59.

Vachudova, M. A. (2019). From Competition to Polarization in Central Europe: How Populists change Party Systems and the European Union. Polity 51(4): 689-706.

Van Hecke, S. (2009). Europeanization and Political Parties: The Partido Popular and its Transnational Relations with the European People's Party. Journal of International Iberian Studies 22(2): 109-124.

Van Hecke, S. (2010). Do Transnational Party Federations Matter? (... and Why Should We Care?). Journal of Contemporary European Research 6(3): 395-411. 